\title{
Manifestation of Indian Miniature Style in the Paintings of Nicholas Roerich
}

\author{
Jyoti Saini and Ila Gupta \\ Department of Humanities and Social Science, Department of Architecture and Planning \\ Indian Institute of Technology Roorkee. Uttarakhand, India. \\ Email ids: jyotisainioo4@gmail.com, ilafap@gmail.com
}

\begin{abstract}
India is symbolized by the diversity of its art and culture from epochs. From a global perspective, acculturation could be a topic of present day study for visual artists and other cultural practitioners. Cultural assimilation has been a much debated issue in respect of Indian paintings. Nowadays or even in the past, artists have been coming to India to be enamored by its natural beauty, culture, religious beliefs and philosophy, ceremonies and many more practices. Among these artists, one key figure from the last centenary was the Russian maverick- Nicholas Roerich, who was very much influenced by Indian cultural ethos. Roerich has done exercise with Indian theme in western techniques and depicted the several sights of beauty of nature and the figures in Indian style. Roerich has contributed significantly to Indian modern paintings during art- revivalism. The significance of portrayal of Indian style has been defined on theoretical perception of renowned art critics. Further, Indian miniature stylistic forms have been pointed out through handmade drawings with the help of Photoshop software as a tool. Thus, this paper is an attempt to critically evaluate the influence of Indian culture especially Hindu culture on the works of Nicholas Roerich.
\end{abstract}

Keywords: Nicholas Roerich, cultural assimilation, Indian art, Hindu religion

\section{Introduction}

India has had a close affinity with excursionists from the ages. It bears the stamp of our ancient culture, which a unique feature that keeps visitors coming from different countries across the world spellbound. India has a curious amalgamation of culture, history, religious beliefs, and philosophy. People of non-Indian origin like artists adopted the Indian culture over time because the idea of Indian nationalism has an immensely broad base. Artists like Okakura Tenzing, Kampo Arai, Xu Beihong,Yokoyama Taikan, Nanpū Katayama, Shôkin Katsuta, Nicholas Roerich, Lama Anagarika Govinda, Vasiliy Vereshchagin, George Keyt, and Svetoslav Roerich, have worked in the past as well as Waswo x waswo, Sterre Sharma, Olivia Dalrymple, Yuriko Lochan, Alfred J.Valerio, Alla Dulh and many more are still painting India. Foreigners are often very influenced by the peaceful life of villages. An artist from Saint- Petersburg, Alla Dulh says, "Life for a foreigner is particularly comfortable in Indian villages". (Kamalakaran, 2012) Most artists move from one place to another and make a mental picture of India after their impressions and artistic observation. For some, India is a land of mountains, hills, rocks,

(c) AesthetixMS 2016. This Open Access article is published under a Creative Commons Attribution Non-Commercial 4.0 International License (http://creativecommons.org/licenses/by-nc/4.o/), which permits non-commercial re-use, distribution, and reproduction in any medium, provided the original work is properly cited. For citation use the DOI. For commercial re-use, please contact editor@chitrolekha.com 
soils and various climates but to others, India is full of religious thoughts and beliefs, social life, customs and traditions that encouraged and motivated the minds and the hearts of foreign artists to paint and stay in India. Some of them artists were immensely influenced by India and its culture and they made India their home and eventually settled. One among those artists is Nicholas Roerich who have come from Russia and influenced by culture, religion, beauty of nature and, philosophy of India.

Thus, the present study will be based on an overview of the portrayal of Indian miniature forms in the paintings of Russian artist Nicholas Roerich. The role of Indian miniature aspects has been observed on the bases of visual narratives. In this context, the depiction of Indian miniature aspects has been observed on the bases of symbolic significance, theme, and other related aspects of application. In which, the raag- ragini figures have been frequently depicted to project Indian miniature forms in ancient paintings and Roerich' Paintings display.

\section{Nicholas Roerich: A Glimpse of His Life}

Nicholas Roerich, a Russian artist, theatrical designer, philosopher, archeologist, and explorer who was born in Saint Petersburg, Russia on $9^{\text {th }}$ October, 1874 . He lived in many countries but after many expeditions, made India his home. He has wrote in the praise of India, "India's heart is reaching for the infinite Russia. The great Indian magnet is attracting Russian hearts. How joyful it is to see vitality in Indo-Russian ties... There exists beauty in the Indian-Russian magnet." (Krassilchtchikov, 2003) His father, Konstaintin Roerich was a well- esteemed lawyer and notary. He has two sons George de Roerich and Svetoslav Roerich and his Wife, named by Helena Ivanovna Roerich was an eminent Russian writer and philosopher. In 1923, after his toughest excursion to central Asia, he settled in the beautiful hills of Nagar, Himachal Pradesh with his family. In the words of his elder son George Roerich about this place, "In this far valley of Kullu blend keen mountain air and warm southern sun. Here, too, wonderfully blend races, languages, religions, arts and the natural phenomena of many diverse climes, to create anew a veritable paradise alike for the scientist who looks only to the present and for him, who reckons man's and Nature's story in thousand-year units" (Kamalakaran, 2012). Roerich was a staunch lover of the beauty of nature. Numerous painted series on Himalayan scenes shows his love for the nature.

In 1928, Roerich, an Indophile, has established the well-known Urusvati (Light of Morning Star) Institute of Himalayan Studies. He gave a great contribution to this world to protect our cultural treasures and values by his pact named by 'Roerich Pact' (paxcultura). "When the whole earth will be covered by the Banner of Peace, protecting cultural treasures, there will be no field for war" (Hall, 2015), he stated to identify the sign as the 'Red Cross of Culture' which was created by him. Roerich was wholly influenced by Hindu spiritualism, culture and beauty of nature. Roerich has stated 'the creation of art was a sacred activity that could lead to highest spiritual path'. It is this philosophical concept that saw its physical manifestation in many paintings that depict intense mountains capes. Roerich has left behind over 7000 sketches and paintings in his life time. He was fascinated by religious mythology. He discovered ancient Buddhist text. 
After coming in India he has depicted a series of mystical and symbolical paintings of the Himalayas as well as he has portrayed some Hindu mythological paintings. He was influenced by Hindu Deities. Roerich gave such an expression of Hindu scriptures in his paintings.

\section{His Artistic Oeuvre}

The painterly voyage of Roerich's career has been started from his graduation in 1893 from the Imperial Academy of Fine Arts. In his early period his life he was used to paint the history of Russia. He had joined the studio of Arkhip Kuindzhi, was a great landscapist who has brought a major development in his artistic life. He was influenced by his Guru Kuindzhi's style and also distinguished critic Vladimir Stasov during 1895 in his student life. He was the Stasov who assured him that the folk myths of Russia are influenced by Mahabharata and Shahnameh, the scriptural sagas of India and Persia. In 1897, Roerich planned to depict 12 works on the major historical documents of earlier state of Russia. He completed only one painting out of 12. But from this painting entitled "messenger: tribe has risen against tribe", he has gained the title of 'artist' on a national status.

\section{A Brief about Indian Miniature}

The folklore of paintings in India dates back to the pre-historic times. Bhimbetka and Panchmarhi caves show traces of farming, hunting, and dancing scenes drawn on rocks in black or mud colors. Buddhism influenced the art of painting as evident in Ajanta paintings depicting Buddha's life stories. The paintings of Pala miniature of Eastern India dating back to about 11th century are the initial proofs of miniature painting practice. The different schools of miniature painting emerged in different geographical locations in the region at various points in history. These schools included Pala, Orissa, Jain, Mughal, Rajasthan, and Nepal. (Beach, 1992)

However, miniature paintings' the golden period was the 16th century when the Mughals, rulers of Deccan and Malwa, and Hindu Sovereigns of Rajasthan provided substantial patronage to the art. Various major paintings schools came into existence and flourished in different parts of the region. They can be largely divided into Mughal, Rajasthan, and Deccan schools. The Rajput / Rajsthani School began to absorb elements of Mughal style due to the evolving alliances between the Mughals and Rajput kingdoms. The hill regions of Northern India including Basoli, Guler, Kangra, Bilaspur, Kullu, and Mandi saw the emergence of Pahari School with the Kangra School of painting becoming noticeable in 18th century. The latter though influenced by Rajasthani and Mughal miniatures developed a distinctive style. The painting styles that developed during the Mughal reign included elements of Hindu, Persian, and European styles. Portraits became an important part of paintings familiarized during the reign of Mughal king Akbar. Besides a number of durbar scenes, portraits, bird, animal and flower studies were also executed during his period. The famous painters of Jahangir are Aqa Riza, Abul Hasan, Mansur, Bishan Das, Manohar, Goverdhan, Balchand, Daulat, Mukhlis, Bhim and Inayat. (Guy and Britschgi, 2011) Rajasthan witnessed the development of several regional schools of painting during

this time like Mewar, Bundi-Kota Kalam, Jaipur, Bikaner, Kishangarh and Marwar 
schools. Paintings depicted themes such as court scenes, gardens, forests, palaces, hills and valleys, deserts, life of Lord Krishna, love scenes, hunting scenes, and animal fights. The different painting schools could be identified by the subjects depicted and use of colors in the paintings. Other important components of Rajasthani miniatures are Ragmala (representing ragas in classical music), Gita Govinda, Ramayana, and Bhagavata Purana. Unlike Mughal painting which is primarily secular, the art of painting in Central India, Rajasthani and the Pahari region etc. is deeply rooted in the Indian traditions, taking inspiration from Indian epics, religious texts like the Puranas, love poems in Sanskrit and other Indian languages, Indian folk-lore and works on musical themes. The cults of Vaishnavism, Saivism and Sakti exercised tremendous influence on the pictorial art of these places. Among these the cult of Krishna was the most popular one which inspired the patrons and artists. The themes from the Ramayana, the Mahabharata, the Bhagavata, the Siva Purana, the Naishadacarita, the Usha Aniruddha, the Gita- Govinda of Jayadeva, the Rasamanjari of Bhanudatta, the Amaru Sataka, the Rasikapriya of Kesavadasa, the Bihari Satasayee and the Ragamala etc., provided a very rich field to the painter who with his artistic skill and devotion made a significant contribution to the development of Indian painting. Miniature paintings have long been favored as souvenirs by tourists - of foreign origin and Indians living abroad - visiting India.

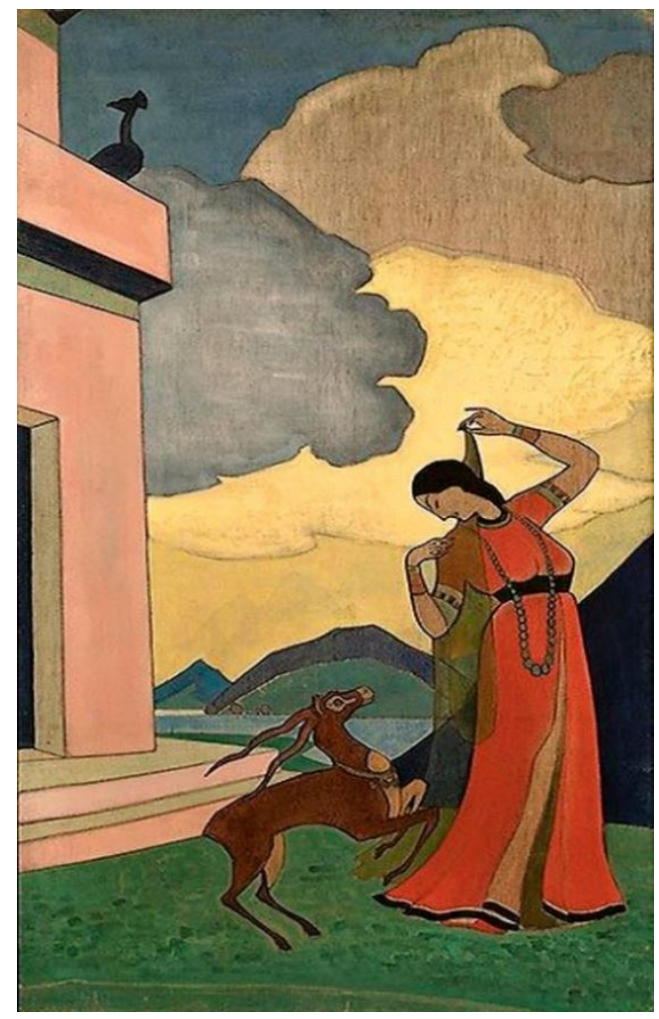

Fig. 1 Song of the Morning, Nicholas Roerich, 1920

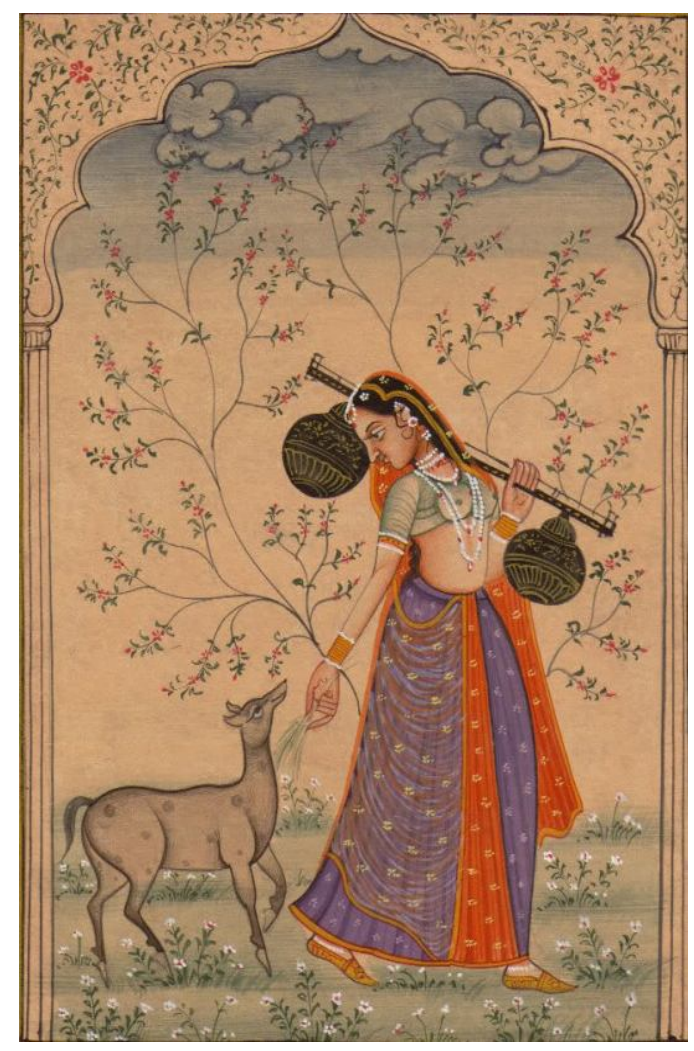

Fig. 2 Ragamala Ragini, Indian Miniature, Medieval Period ( $16^{\text {th }}-17^{\text {th }}$ century)

Fig. 1 Source: https://www.wikiart.org/en/nicholas-roerich/song-of-the-morning-1920

Fig.2 Source: http://www.artnindia.com/product/rajasthan-miniature-painting-of-music-ragamala-indianrajput-todi-ragini-art/ 


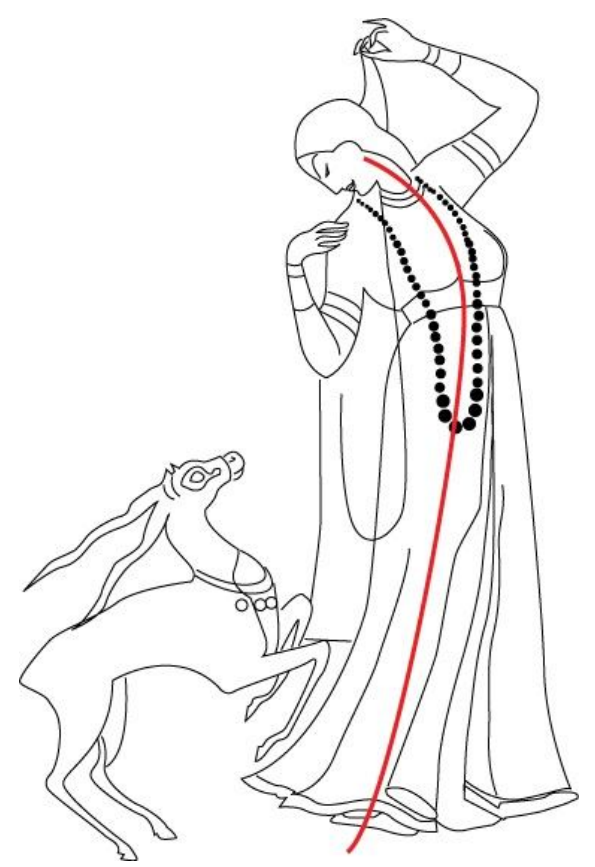

By Author

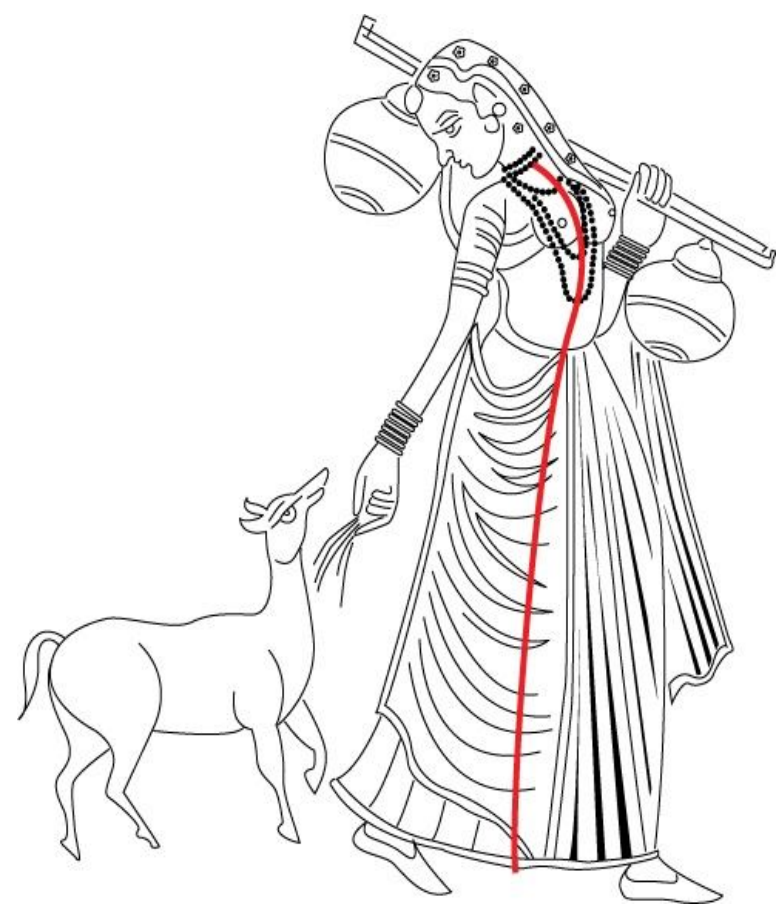

By Author

Roerich's painting (Fig.1) 'Song of the Morning' has been portrayed in Indian miniature style and very familiar with the Rajasthani style paintings. The painted lady figure is looking like the character of Ragamala- Ragini, which is quiet similar with that miniature style. Here can be seen the similarities and dissimilarities with the image of Indian miniature painting of medieval period. In both of the paintings, the character has seen with side profile and almost in the same standing pose. In Roerich painting, the lady has been painted in traditional Indian dress and has worn transparent scarf with red gown. In (Fig.2) Rajasthani miniature painting, the lady figure is painted in ghagra in violet color, kanchli with green color and transparent scarf in orange color. Abbasi stated that "in Rajput paintings the sensuality has presented-wearing transparent fabrics draped around their bodies. (2013)" In Roerich's painting figure has worn jewelry on her neck and her skin tone is also painted with brown color, which shows Indian climatic difference. Rajasthani women has been wearing Gems-studded gold and silver ornaments. In the painting of Roerich, the sky, mountains, house, water, peacock, deer has been depicted which are the main characteristics of Indian miniature paintings. Roerich has painted peacock on the terrace in side face which is looking the symbol of waiting. And the lady figure and deer seems in the dancing pose. Looking at the picture, it can be observed that the painting is entirely a stereotype of that old miniature tradition and only some roughdrafting has been done by the artist. Roerich has avoided such kind of detailing, which always been remained an identity of Indian miniatures but he was strongly influenced by those paintings. Moreover, such detailing and flora and fauna are the main features of Indian miniature style but in case of Roerich, he entirely made these elements in a simple 
but impressive manner. Roerich has not depicted rhythm in the lines of clouds depiction. In this painting, Roerich has created mountains in his own style of creativity.

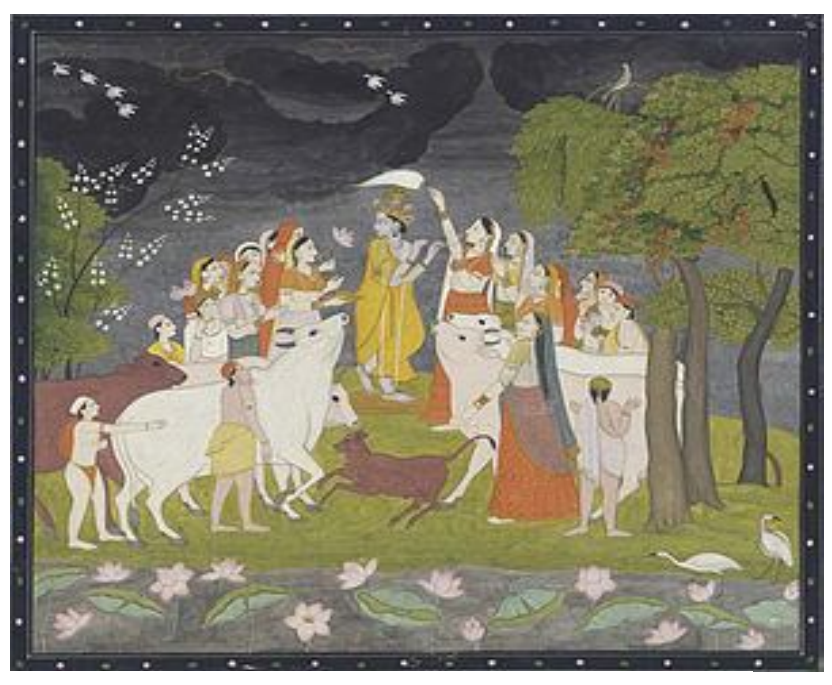

Fig. 3 Krishna Playing a Flute, 1790- 180o, Rajput Period

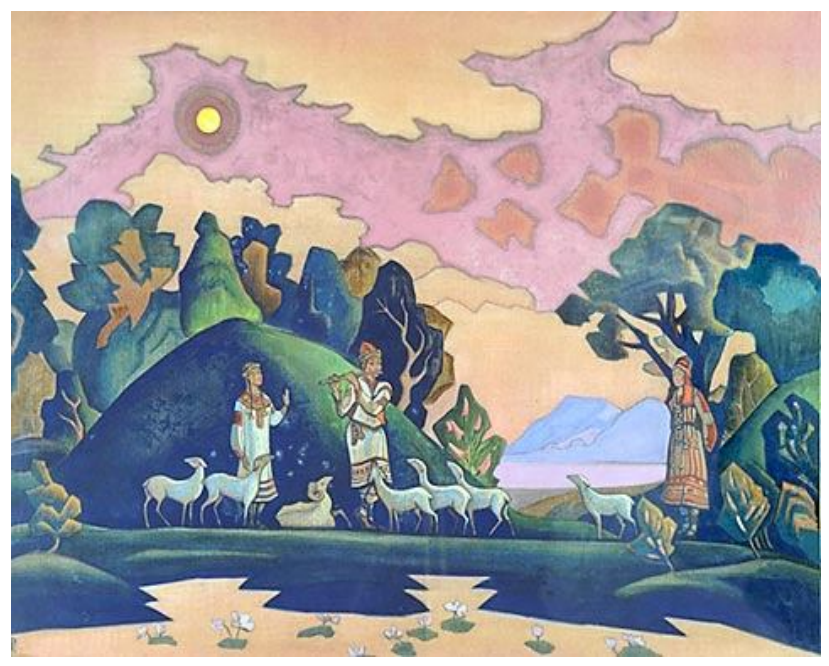

Fig.4 Nicholas Roerich, Krishna- Lel, 1932

Fig.3 Source: https://en.wikipedia.org/wiki/Kangra_painting

Fig.4 Source: https://www.wikiart.org/en/nicholas-roerich/krishna-lel-1932

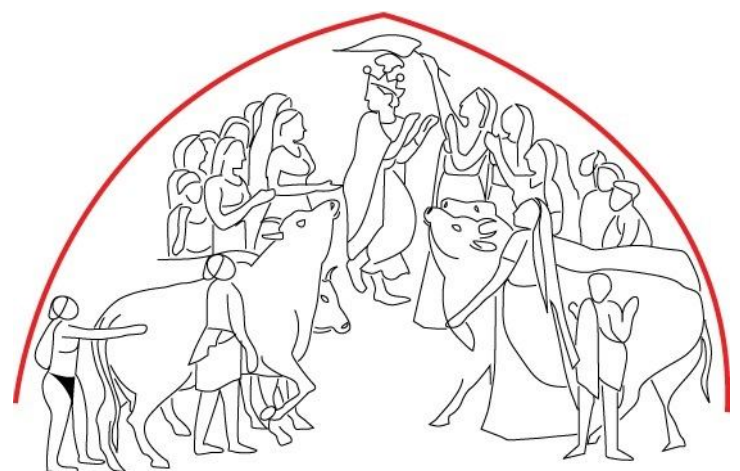

By Author

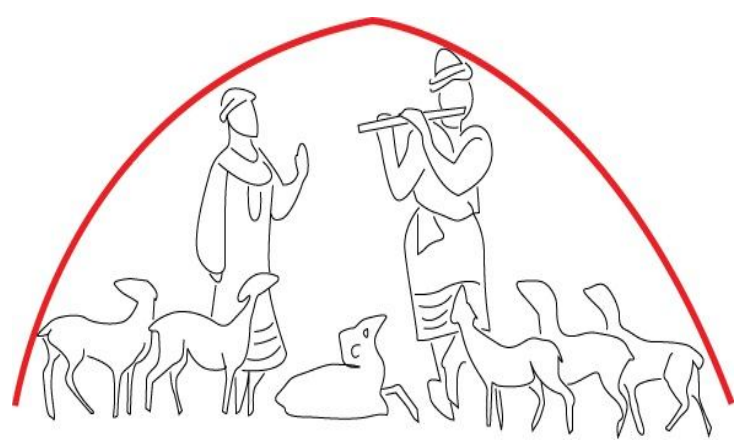

Roerich's painting (Fig.4) 'Krishna- Lel' is totally based on mythology. He has depicted Lord Krishna who is the creator of all the beings in Hindu religion. Krishna has been portrayed as a heroic character in Hindu scriptures like Mahabharata and Bhagvad Gita. From ancient times, Krishna has been painted in the Indian paintings as a dominant character. In this painting, Lord Krishna is playing the flute and many deer seem to be engrossed in the sweet melody of flute around Krishna. Bright yellow and purple color has been applied as the main colors. Trees, mountains, goats, cows and the sky have been beautifully depicted in the background of the painting. Roerich has created the background from his own style of originality.

In the contrary, in (Fig.3) 'Krishna Playing a Flute' from Rajput period, known commonly as Krishna-Lila. The miniatures of Rajasthani style are also famous as Rajput school and during the 
early $17^{\text {th }}$ century, the major patrons of this style were the kings of Mewar, Bundi, Kotah, Jodhpur, Jaipur, and Kishangarh. The main concept of these paintings was related with the heroic tales of Lord Krishna; "the musical mode, the epics and romances, religious theme and love theme" (Reiff 1959). In some miniatures, the blue-god Krishna is seen dancing in the lush forests and every young woman's' and cows' eye is drawn to him.

River Yamuna and lotus are painted in the foreground of both paintings. It seems, Roerich has depicted Lord Krishna in Kullu's garb. There are few figures has depicted by Roerich rather there are so many women figures and animals are portrayed in Rajput painting. In ancient painting, artist has used black and grey color to create the scene of night. On the other hand, Roerich has showed the scene of day by using light colors. Both depictions are representing the scene of Krishna- Lila which is playing in an open heaven of Nature. Coomaraswmy (1912) concluded that:

"in the human figure there is great concentration and intensity of emotions; eye looks into eye, as Blake would have drawn it, hand clasps hand, the very animals are spellbound by the sound of Krishna's flute, the elements obey the rags and raginis".

In such fusion of genuine romance, the female imagery has encountered numerously in the offering condition for their one heroic god (Archer, 2004).

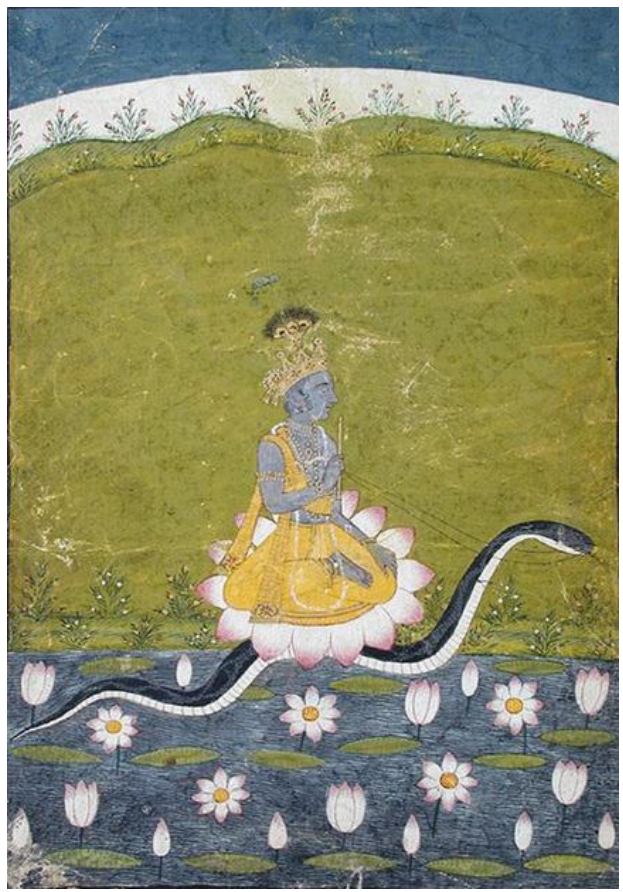

Fig. 5 Krsna. Kalidipak Ragaputra of Kedar, Ragamala Series, ca. $1710,(27$ cm x 20 cm)

Fig.5 Source: https://www.flickr.com/photos/thesandiegomuseumofartcollection/6125128310/in/photolistakfTfw-8nytWY 


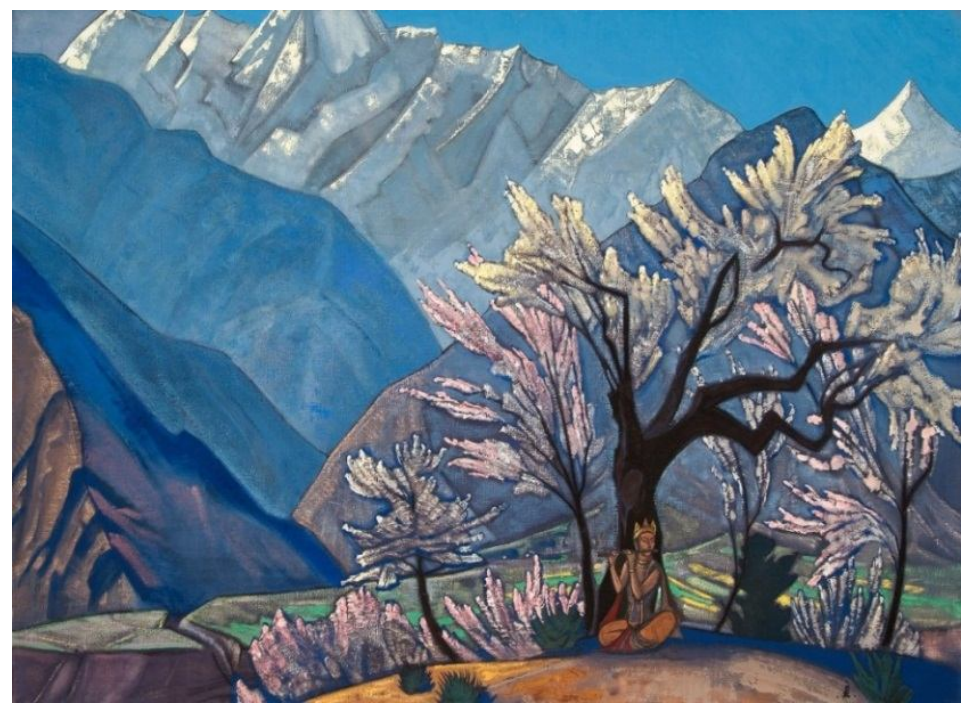

Fig. 6 Nicholas Roerich, Krishna- Spring in Kullu, 1930, tempera, 74 X 118 cm

Fig.6 Source: https://www.wikiart.org/en/nicholas-roerich/krishna-spring-in-kulu-1930

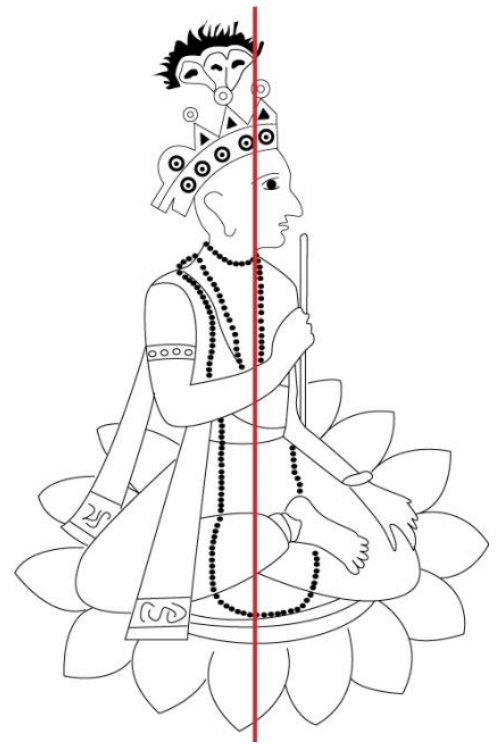

By Author

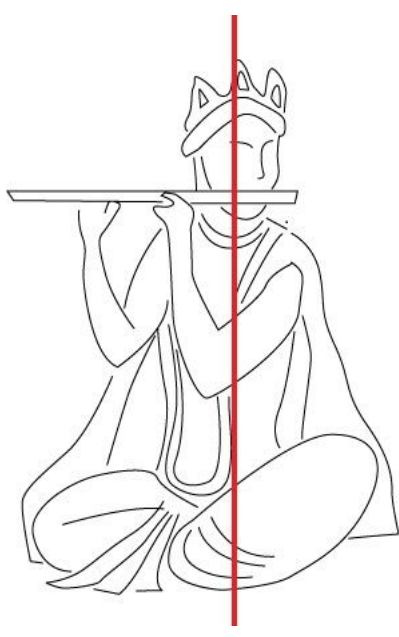

By Author

Anotner dest exampie or minau rengious theme of Roerich's painting is 'Krishna' from the Kullu series (Fig.6). In this painting, Lord Krishna is sitting on a hill under the tree and playing the flute. The scene of the painting shows the spring season of Kullu. High Mountains are depicted in the background of the painting which shows the style of creativity of Roerich. 'Lord Krishna' is portrayed in miniature style. Krishna is engrossed in playing flute in sitting pose under the tree. In Hindu religion, Yellow color is considered very auspicious and sacred (Nezhad and Kavehnezhad, 2013). So Lord Krishna is showed in yellow color dress. Likewise, it can be seen in (Fig. 5) 'Krsna. Kalidipak Ragaputra of Kedar' from ragamala series, Krishna is sitting on a side pose. He has taken 
flute in his hand and wearing a yellow colored dress. Krishna seems to be seated near the bank of river Yamuna. Krishna is the centre of attraction in both of the paintings.

\section{Conclusion}

Roerich has represented Indian components in his paintings. Farther, he has created many paintings like 'Song of the Waterfall' (1920), 'Language of Bird' (1920), 'Krishna' in Kullu series (1929), 'Krishna' (1936), 'Ramayana' (1937), 'Krishna Magic Flute' (1938), 'Krishna' (1946). There is a very important role of Hindu religious art in his paintings. In this context, his numerous paintings have a true glimpse of indigenous art of miniatures. Some of his paintings have also been made to capture other mythological themes of Hindu religion. In all his artistic voyage, he preferred landscapes of Kullu hills and mostly made open space paintings which may be owing to his love for valley of Kullu. The fusion of nature and mythology can be seen in his most of the paintings. The paintings show that he has portrayed the real character of the Hindu mythology as well as Indian miniature. At the present time, some of his paintings can be seen in Nicholas Roerich Museum, New York, Karnataka Chitrakala Parishath, Bangalore and Nicholas Roerich Art Gallery, Naggar, Himachal Predesh. India.

\section{References}

Abbasi, M. S. (2013). A Comparison Study between Rajput and Mughal Miniature Paintings. Indian Journal of Research Paripex.

Archer, Kenneth, Jacqueline Decter, and Nicholas Roerich Museum. "Nicholas Roerich: The Life and Art of a Russian Master." Dance Research Journal 22.2 (1990): 31.

Archer, Kenneth, and Nikolaj Konstantinovicİ Rerich. Roerich: East \& West: Paintings from the Nicholas Roerich Museum. Bournemouth: Parkstone, 1999. Print.

Beach, M. c. (1992). Mughal and Rajput Painting, Part 1, Volume 3. Cambridge University Press.

Coomaraswamy, K. A. (1912). "Rajput Painting. The Burlington Magazine Publications Ltd, 20 (108), 314$319+322-325$.

Guy, J. and Britschgi, J. (2011). Wonder of the Age: Master Painters of India, 1100-190o. Metropolitan Museum of Art.

Levine, B. D. (1971). The Mountain, the Mirror, and the Mandala: A Search for Krishna in Indian Painting. Wayne State University Press, 13 (2), 142-150.

Mccannon, J. "In Search of Primeval Russia: Stylistic Evolution in the Landscapes of Nicholas Roerich, 18971914." Cultural Geographies 7.3 (2000): 271-97.

Randhawa, S. M. (1981). Indian Miniature Painting. New Delhi: Roli Books Internationa.

Randhawa, S. R. (1980). Kishangarh Painitngs Bombay: Vakilr, Feffer \& Simons Limited.

Reiff, R. (1959). Indian Miniatures, The Rajput Painteres, edited, with the Introduction and Notes. Vewrmont \& Tokyo, Japan :Charles E. Tuttle Company, Rutland.

Roerich, Nicholas. The Roerich Pact and the Banner of Peace. Whitefish, MT: Kessinger, 2007. 
69 | The Chitrolekha Journal on Art and Design, Vol. 1, No. 1, 2017

Sharma, C. L. (1980). A Brief History of Indian Paintings. Meerut Delhi: Krishna Prakashan, Goel Publishing House.

Tiwari, N. J. (1985). Goddess Cult in Ancient India. Sandeep Prakashan.

See- http://ccrtindia.gov.in/miniaturepainting.php 